\title{
A DIGNIDADE DA PESSOA HUMANA E SUA DIMENSÃO INTERSUBJETIVA NA TUTELA DOS DIREITOS FUNDAMENTAIS DO IMIGRANTE
}

\author{
(HUMAN DIGNITY AND ITS INTERSUBJECTIVE DIMENSION \\ TOWARDS THE PROTECTION IMMIGRANT'S FUNDAMENTAL RIGHTS) \\ ${ }^{1}$ Rogério Luiz Nery da Silva \\ ${ }^{2}$ Cristiane Brum dos Santos
}

\section{RESUMO}

A presente pesquisa adota por tema geral a efetividade dos direitos humanos e por recorte efetividade dos direitos dos imigrantes. O problema está identificar o elemento central de justificação da exigibilidade de direitos dessas pessoas. A pesquisa encontra por objetivos identificar o processo de reconhecimento dos direitos humanos e fundamentais, conhecer e examinar possíveis conceitos de dignidade da pessoa humana e investigar se a dimensão intersubjetiva da dignidade é apta e suficiente a justificar a tutela dos direitos fundamentais do imigrante. $\mathrm{O}$ método adotado busca ser hipotético-dedutivo, com pesquisa qualitativa e exploratória.

Palavras-chave: Direitos Humanos; Direitos Fundamentais; Imigrantes; Dignidade Humana; Dimensão Intersubjetiva Da Dignidade.

\begin{abstract}
This research about the general theme of human rights' effectiveness sets the view over the effectiveness of immigrants' human rights. The issue is to identify the justification element for the enforceability of the argument. It aims to identify the human rights recognition process and the link to fundamental rights as well, all this to study the possible concept of human dignity and its empowerment, investigating whether human dignity by its intersubjective dimension is adequately reasonable as to justify wide fundamental rights' protection to the immigrants. The adopted method is broadly hypothetical-deductive, based on qualitative and exploratory research.
\end{abstract}

Key-words: Human Rights; Fundamental Rights; Immigrants; Human Dignity; Intersubjective Dimension Of Dignity.

\footnotetext{
${ }^{1}$ Pós-doutor em Droits Fondamentaux/Science Politique Université de Paris - CREDOF/ UNIV-PARIS (Paris). Professor Titular PPGD/Mestrado em Direito pela Universidade do Oeste de Santa Catarina -UNOESC, Santa Catarina (Brasil). E-mail: dr.rogerionery@gmail.com

${ }^{2}$ Mestranda em Direito pela Universidade do Oeste de Santa Catarina -UNOESC, Santa Catarina (Brasil). Servidora do Tribunal Regional Federal - TRF (Brasil). E-mail: cris.brum24@ gmail.com
} 


\section{INTRODUÇÃO}

Em tema de direitos humanos e fundamentais, a dignidade da pessoa humana é referida de modo exaustivo para justificar a existência, necessidade e relevância desses direitos. São raras as vozes na doutrina e na filosofia que se opõe à relação umbilical entre a dignidade da pessoa humana e os direitos, revelando-se um valor fundamental na marcha do reconhecimento e da proteção do tratamento digno no patrimônio jurídico e moral da humanidade.

Revisitando o conceito de dignidade da pessoa humana, verifica-se o grau de generalidade da expressão, que não reúne definição uníssona do conteúdo jurídico abrangido pela ideia de dignidade. Faz-se, portanto, necessário busca-la a partir da diversidade de pretensas definições jurídicas, e do perfil multifacetado do homem e do viés dinâmico da coletividade, em contínua transformação. Propõe-se, destarte, adotar a classificação por “dimensões" da dignidade humana como mecanismo de reconhecimento e pertencimento à coletividade.

A dimensão intersubjetiva impõe o dever recíproco de cada homem em assegurar a dignidade do outro, perspectiva que se desloca de uma concepção individualista e parte para uma análise universal. É, portanto, direito de todo o ser humano que lhe seja assegurada a dignidade.

A dimensão intersubjetiva ganha relevo nos atuais e expressivos movimentos migratórios, marcados notadamente pela Primavera Árabe, pela guerra civil na Síria e pelos consequentes êxodos asiático e africano. Isso porque tanto a trajetória quanto a fixação da nova moradia pressupõem o enfrentamento de situações jurídicas relacionadas à existência e tutela de um direito fundamental.

Imperioso, portanto, examinar a verossimilhança da hipótese que relaciona a dimensão intersubjetiva da dignidade à tutela dos direitos fundamentais do imigrante, verificando a possibilidade de o imigrante figurar como titular de direitos fundamentais, a partir dos primados do tratamento digno e da integração no espaço coletivo. Os níveis variados E graduais de realização dessa tutela serão, no entanto, objeto de futuros trabalhos. 
Para tanto, a pesquisa foi construída analisando, de início, o processo de reconhecimento dos direitos humanos e fundamentais e o tratamento jurídico conferido ao imigrante no ordenamento constitucional brasileiro. Na segunda parte do trabalho, analisou-se o conceito de dignidade da pessoa humana e seu valor na temática dos direitos. Ao final, investigou-se o problema de pesquisa proposto, a partir do conteúdo jurídico da dignidade e suas dimensões.

A título de registro, o método hipotético-dedutivo foi aplicado no desenvolvimento desta pesquisa, de natureza qualitativa e de caráter exploratório.

\section{O PROCESSO DE RECONHECIMENTO DOS DIREITOS HUMANOS E FUNDAMENTAIS}

Os primeiros traçados para o processo de reconhecimento dos direitos remontam ao início da civilização, na Grécia Antiga. Comparato (2003, p. 8) identifica que entre os séculos VIII e II a.C., no chamado período axial, a humanidade dá início à construção do conhecimento a partir de sua racionalidade, momento em que passou a ser necessária a designação de direitos e deveres.

No processo histórico de reconhecimento dos direitos, papel central é atribuído às chamadas revoluções burgueses "seiscentistas e setecentistas", assim consideradas, "Revolução Gloriosa" (Inglaterra - 1688), com o reconhecimento da superioridade do Parlamento sobre o poder antes absoluto do rei; a Revolução Americana (Estados Unidos - 1776), com o reconhecimento da limitação do poder de um estado sobre seus colonizados , por derradeiro, a Revolução Francesa (França - 1789), com a limitação do poder do rei perante a Constituição, cada uma a seu turno, foram todas muito importantes para a ressignificação da relação entre Estado e povo ou sociedade e, portanto, para a aceitação dos direitos humanos ${ }^{3}$.

Delas advieram documentos como: a Declaração de Direitos do Parlamento Inglês (1689), a Declaração dos Direitos da Virgínia (1776), a Declaração dos Direitos do Homem e do Cidadão (1789), assim como outros documentos importantes, materializaram formas de resistência sócio-política, pela busca de formalização positiva de conteúdo iluminista, antes

\footnotetext{
3 “"...] foi a Revolução Francesa que constituiu, por cerca de dois séculos, o modelo ideal para todos os que combateram pela própria emancipação e pela libertação do próprio povo. [...]” (BOBBIO, 1994, p. 85).
} 
existente apenas em sede jusnaturalista; esses movimentos tiveram por propósito consubstanciar determinados consensos de direitos de ordem natural em documento único a fim de forçar seu reconhecimento como limitador de poderes dos estados colonialistas e absolutistas.

Em meados do século XX, o término da Segunda Guerra Mundial repercutiu de forma significativa no âmbito da positivação e proteção dos direitos do homem ${ }^{4}$. As graves violações cometidas, o contingente de mortos e a inobservância da necessária dignidade no tratamento dos combatentes, dos prisioneiros e da população civil despertaram a necessidade de um consenso acerca dos titulares de direitos e dos bens jurídicos sujeitos à salvaguarda pela espécie humana.

Um dos mais memoráveis resultados desse anseio internacional se constituiu na Declaração Universal dos Direitos Humanos, proclamada pela Assembleia Geral das Nações Unidas em 1948 e composta por 30 artigos. Bobbio (1994, p. 22) afirma que, embora uma parte das nações não tenha ratificado o documento ${ }^{5}$, este representa um consenso geral de validade dos direitos do homem, de modo que não restariam grandes incertezas quanto à existência desses direitos.

A ressignificação e a representatividade da Declaração Universal dos Direitos Humanos para a coletividade são reforçadas por Schwarz (2011, p. 20), em razão do seu papel chave para o discurso ético e político atual em tema de direitos, da linguagem de direitos formulada e da sua repercussão no plano constitucional internacional, influenciando o conteúdo jurídico de numerosos textos constitucionais internos.

No exame dos direitos humanos e seu recorte como direitos fundamentais, as expressões são utilizadas comumente como semelhantes, representativas de um mesmo objeto. No entanto,

\footnotetext{
4 "O problema, bem entendido, não nasceu hoje. Pelo menos desde o início da era moderna, através da difusão das doutrinas jusnaturalistas, primeiro, e das Declarações dos Direitos do Homem, incluídas nas Constituições dos Estados liberais, depois, o problema acompanha o nascimento, o desenvolvimento, a afirmação, numa parte cada vez mais ampla do mundo, do Estado de Direito. Mas é também verdade que somente depois da Segunda Guerra Mundial é que esse problema passou da esfera nacional para a internacional, envolvendo - pela primeira vez na história - todos os povos" (BOBBIO, 1994, p. 46).

${ }^{5}$ Comparato (2003, p. 222-224) destaca que, a União Soviética, Ucrânia, Rússia Branca, Tchecoslováquia, Polônia, Iugoslávia, Arábia Saudita e África do Sul não ratificaram a Declaração Universal dos Direitos Humanos de 1948.
} 
adotando-se a classificação desenvolvida por Sarlet (2015, p. 29), pode-se dizer que direitos humanos são aqueles que foram reconhecidos e positivados em âmbito internacional, outorgados a todas as pessoas, independentemente do tempo e do povo a que pertencem. Já os direitos fundamentais podem ser entendidos como aqueles positivados no ordenamento constitucional interno de cada Estado ${ }^{6}$.

Pode-se afirmar que direitos fundamentais são aqueles direitos reconhecidos no texto constitucional ou na forma de tratados que foram adotados pelo sistema jurídico nacional, para os quais está o Estado vinculado a respeitá-los em seus limites e promovê-los em prestações. Essa é a subdivisão comumente estabelecida entre direitos civis e sociais. Os direitos civis, também conhecidos como direitos de defesa, seriam aquelas liberdades oponíveis em face do Estado, enquanto que os direitos sociais, de outro norte, seriam prestações pleiteadas ao Estado, para a garantia da igualdade material entre as pessoas.

O duplo caráter dos direitos fundamentais, segundo a qual a dicotomia direitos civisdireitos negativos e direitos sociais-direitos positivos cairia por terra. Torres (2013, p. 65) pontua que a teoria da indivisibilidade dos direitos humanos ganha força no plano constitucional internacional desde a década de 90, razão pela qual os direitos civis podem, também, ter um caráter positivo e os direitos sociais um caráter negativo. Tanto o que, se colhido o ensinamento de Alexy (2015, p. 195-196), para quem deve ser relativizada a concepção de direitos sociais como de cunho necessariamente prestacional, pois também podem assumir um caráter defensivo. ${ }^{7}$ A terminologia adotada pelo autor sugere que sejam utilizados os termos direitos de defesa e direitos a prestações.

Para Bobbio (1994, p. 21), há uma relação de proporcionalidade na realização dos direitos sociais ("poderes") e dos direitos individuais ("liberdades”); a materialização de

\footnotetext{
6 "Em que pese os dois termos ('direitos humanos' e 'direitos fundamentais') sejam comumente utilizados como sinônimos, a explicação mais adotada para a distinção é de que o termo 'direitos fundamentais' se aplica para aqueles direitos do ser humano reconhecidos e positivados na esfera do direito constitucional positivo de determinado Estado, ao passo que a expressão 'direitos humanos' guardaria relação com os documentos de direito internacional, por referir-se àquelas posições jurídicas que se reconhecem ao ser humano como tal, independentemente de sua vinculação com determinada ordem constitucional, e que, portanto, aspiram à validade universal, para todos os povos e tempos, de tal sorte que revelam um inequívoco caráter supranacional (internacional)". (SARLET, 2015, p. 29).

7 “[...]. No âmbito dos direitos em face do Estado [...] os direitos a ações negativas correspondem àquilo que comumente é chamado de "direitos de defesa". Já os direitos em face do Estado a uma ação positiva coincidem apenas parcialmente com aquilo que é chamado de "direitos a prestações” [...]" (ALEXY, 2015, p. 195-196).
} 
poderes condiciona as liberdades a um prejuízo, em proporcionalidade inversa, em que quanto mais poderes, tanto menos liberdades, e vice-versa.

No âmbito do direito constitucional interno, é preciso ter em mente que o processo de redemocratização, com a promulgação da Constituição Federal de 1988, representou um expressivo avanço para o reconhecimento e tutela dos direitos no ordenamento jurídico interno. Piovesan (2013) assinala que se trata do texto constitucional pátrio mais amplo e denso em tema de direitos ${ }^{8}$.

Examinado o texto constitucional por seus dispositivos, na perspectiva de seus titulares e destinatários, é indene de dúvidas que aos brasileiros está assegurada a totalidade dos direitos, com mínimas distinções entre os brasileiros natos e os estrangeiros naturalizados. Já no tocante aos estrangeiros residentes ou não, a jurisprudência do Supremo Tribunal Federal, representada por voto do Ministro Celso de Mello9 ${ }^{9}$, determina reconhecer igual extensão, salvo casos específicos, portanto, quanto aos imigrantes se tornarem titulares de direitos fundamentais, temse objeto para rica e desafiadora pesquisa no sentido de buscar reconhecer-lhes a garantia mais completa possível desses direitos, como forma de declaração de sua própria dignidade.

O ordenamento jurídico brasileiro reconhece direitos aos estrangeiros residentes no país, consubstanciados no próprio texto constitucional ${ }^{10}$ e em importantes diplomas legais, a exemplo do Estatuto do Estrangeiro ${ }^{11}$ e do Estatuto do Refugiado. No entanto, os níveis de proteção dos direitos civis e a possibilidade de se tornar titular de direitos sociais pelo estrangeiro se mostram tema complexo e que deve ser objeto de estudo, notadamente em

\footnotetext{
8 “ [...] a Carta de 1988, como marco jurídico da transição ao regime democrático, alargou significativamente o campo dos direitos e garantias fundamentais, colocando-se entre as Constituições mais avançadas do mundo no que diz respeito à matéria" (PIOVESAN, 2013, p. 85).

9 “o fato de o paciente ostentar a condição jurídica de estrangeiro e de não possuir domicílio no Brasil não lhe inibe, só por si, o acesso aos instrumentos processuais de tutela da liberdade nem lhe subtrai, por tais razões, o direito de ver respeitadas, pelo Poder Público, as prerrogativas de ordem jurídica e as garantias de índole constitucional que o ordenamento positivo brasileiro confere e assegura a qualquer pessoa que sofra persecução penal instaurada pelo Estado" (STF, HC 94016 MC/SP, rel. Min. Celso de Mello, j. 7/4/2008).

${ }^{10}$ Conforme artigo 5 $5^{\circ}$ caput, da Constituição da República Federativa do Brasil: "Todos são iguais perante a lei, sem distinção de qualquer natureza, garantindo-se aos brasileiros e aos estrangeiros residentes no País a inviolabilidade do direito à vida, à liberdade, à igualdade, à segurança e à propriedade, nos termos seguintes: [...]" (BRASIL, 1988).

11 Conforme artigo 95 da Lei $\mathrm{n}^{\circ}$. 6815/1980: “O estrangeiro residente no Brasil goza de todos os direitos reconhecidos aos brasileiros, nos termos da Constituição e das leis.” (BRASIL, 1980).
} 
atenção aos episódios contemporâneos com seguidos e volumosos movimentos migratórios a ocorrer pelo mundo e também repercutindo sobre o Brasil ${ }^{12}$.

Os deslocamentos voluntários ou involuntários de pessoas, com fins de mudança do local de viver, habitar, trabalhar ou se realizar como seres humanos traduzem as inquietudes vivenciadas por essas pessoas em seus estados de origem, assim como permite projetar a vulnerabilidade sofrida pelos migrantes ainda depois de deixar a origem, já quando em deslocamento e mesmo nos destinos a que chegam. A iniciativa de buscar além das fronteiras nacionais a realização do conteúdo essencial de sua dignidade como pessoa humana é impulsionada por pressões geralmente irresistíveis, mas, ainda depois de alcançada "terra nova", as tensões e insuficiências morais e materiais permanecem presentes, apenas substituindo os pavores antecedentes, mas, de certa forma, renovam incertezas, agora de outra natureza, mas também indesejáveis a uma vida em paz e feliz. As condições de igualdade material com os cidadãos, os termos e limites segundo o ideal de justiça social, a principiologia do direito, a legislação aplicável constituem objeto do mais desafiador dos estudos.

\section{O CONCEITO DE DIGNIDADE DA PESSOA HUMANA}

A dignidade da pessoa humana desponta enquanto valor, princípio ou regra em um número significativo de documentos em âmbito interno e internacional. Isso porque a construção histórica e o processo de reconhecimento dos direitos humanos e fundamentais revelaram aos povos das mais variadas culturas a indispensabilidade do tratamento e respeito humanitário dignos.

O conteúdo da dignidade denota um conceito aberto, vago e impreciso, para o qual não existe uma definição jurídica ${ }^{13}$. Comumente, é referida como fundamento para a própria existência dos direitos humanos e fundamentais, no sentido de que o nascedouro dos direitos

\footnotetext{
${ }^{12}$ Segundo dados do CONARE, o Brasil recebeu no exercício de 201528.670 solicitações de refúgio.

13 "Um dos poucos consensos teóricos do mundo contemporâneo diz respeito ao valor essencial do ser humano. Ainda que tal consenso se restrinja muitas vezes apenas ao discurso ou que essa expressão, por demais genérica, seja capaz de agasalhar concepções as mais diversas - eventualmente contraditórias -, o fato é que a dignidade da pessoa humana, o valor do homem como um fim em si mesmo, é hoje um axioma da civilização ocidental, e talvez a única ideologia remanescente" (BARCELLOS, 2011, p. 125).
} 
teria por razão a proteção da dignidade da pessoa humana enquanto qualidade intrínseca e inerente.

Na concepção de Sarlet (2009, p. 17-20), o problema da ausência de definição e delimitação de um conceito para a dignidade da pessoa humana justifica sua imprecisão e polissemia e, ainda, possibilita compreender o porquê de a dignidade ser reconhecida de maneira quase unânime como valor fundamental do ser humano. $\mathrm{O}$ autor destaca, por outro lado, que não há dúvida de sua concretude, pois é possível identificar sua violação.

Dentre os documentos internacionais, é imperioso o registro da Declaração Universal dos Direitos Humanos de 1948, proclamada pela Organização das Nações Unidas ${ }^{14}$, da Carta Africana dos Direitos Humanos e dos Povos ${ }^{15}$, datada de 1981, e da Declaração Islâmica Universal dos Direitos Humanos ${ }^{16}$, também de 1981. Como três Cartas que pretenderam ser universais na disciplina dos direitos ${ }^{17}$, percebe-se em todas que a proteção e realização da dignidade da pessoa humana é um discurso recorrente.

No que concerne ao plano de positivação, Sandkühler (2013, p. 125-127) assinala que no ordenamento jurídico alemão implantou-se a indissociabilidade entre a dignidade da pessoa humana e os direitos, pois "a dignidade é condição de possibilidade do direito [...] e sem o direito correto, que implementa os direitos humanos positivados na democracia, não há proteção da dignidade humana". É digno de nota, portanto, que no plano constitucional alemão, a dignidade da pessoa humana é concebida como um bem de significativo valor, um bem jurídico intocável da $\operatorname{pessoa}^{18}$, isso em atenção a sua positivação no texto da Grundgesetz (ALEMANHA, 2005, p. 177).

\footnotetext{
${ }^{14}$ Artigo I da Declaração Universal dos Direitos Humanos da ONU de 1948: "Todos os seres humanos nascem livres e iguais em dignidade e direitos. São dotados de razão e consciência e devem agir em relação uns aos outros com espírito de fraternidade" (ONU, 1948).

${ }^{15}$ Artigo $5^{\circ}$ da Carta Africana dos Direitos Humanos e dos Povos de 1981: "Todo indivíduo tem direito ao respeito da dignidade inerente à pessoa humana e ao reconhecimento da sua personalidade jurídica. Todas as formas de exploração e de aviltamento do homem, nomeadamente a escravatura, o tráfico de pessoas, a tortura física ou moral e as penas ou tratamentos cruéis, desumanos ou degradantes são proibidos". (CARTA AFRICANA DOS DIREITOS HUMANOS E DOS POVOS, 1981).

16 "CONSIDERANDO que os direitos humanos decretados pela Lei Divina objetivam conferir dignidade e honra à humanidade e que foram elaborados para eliminar a opressão e a injustiça" (DECLARAÇÃ̃O ISLÂMICA UNIVERSAL DOS DIREITOS HUMANOS, 1981).

${ }^{17}$ Conforme Baez e Mozetic (2013, p. 19-21).

${ }^{18}$ Artigo $1^{\circ}$ da Grundgesetz: “A dignidade da pessoa humana é intocável. Observá-la e protege-la é dever de todos os poderes estatais.” (ALEMANHA, 2005, p. 177).
} 
No plano constitucional brasileiro, a dignidade da pessoa humana foi alçada ao posto de fundamento da República Federativa do Brasil ${ }^{19}$. Piovesan (2013) elucida que o caráter principiológico dos textos constitucionais ocidentais é consectário do colapso do positivismo jurídico em meados do século XX. Assevera que os regimes nazista e fascista e o desfecho da Segunda Guerra Mundial impulsionaram uma reorientação do Direito, até então restrito aos códigos, para se reaproximar da ética de matriz kantiana e, portanto, da dignidade da pessoa humana.

Depreende-se da lição da autora que, nesse novo Direito, um "direito de princípios”, a dignidade da pessoa humana detém papel fundamental, na qualidade de um "supraprincípio" a guiar todo o ordenamento jurídico. É no valor da dignidade da pessoa humana que o Direito, tanto no plano interno quanto no plano internacional, encontra razão de ser, como um vetor axiológico de ética e justiça ${ }^{20}$.

Ao tempo em que destaca a qualidade de princípio fundamental conferida à dignidade da pessoa humana pela Constituição pátria, Sarlet (2015) critica a concepção segundo a qual a dignidade é o fundamento de todos os direitos fundamentais. Defende como inegável sua qualidade de valor jurídico fundamental da comunidade e seu papel precípuo na aplicação, integração e interpretação de todo o ordenamento jurídico, porém refuta a tese de que os direitos fundamentais tenham por fundamento absoluto a dignidade da pessoa humana, quando, em verdade, ela se configura em explicitações de maior ou menor grau em cada um deles.

Como conceito de dignidade da pessoa humana, termo que entende mais adequado do que dignidade humana, que seria da pessoa em abstrato, Sarlet (2015, p. 102) concebe-a “[...] como qualidade intrínseca da pessoa humana, é algo que simplesmente existe, sendo

\footnotetext{
${ }^{19}$ Artigo $1^{\circ}$ da Constituição da República Federativa do Brasil de 1988: "A República Federativa do Brasil, formada pela união indissolúvel dos Estados e Municípios e do Distrito Federal, constitui-se em Estado Democrático de Direito e tem como fundamentos: I - a soberania; II - a cidadania; III - a dignidade da pessoa humana; IV - os valores sociais do trabalho e da livre iniciativa; V - o pluralismo político". (BRASIL, 1988).

20 "Assim, seja no âmbito internacional, seja no âmbito interno (à luz do Direito Constitucional ocidental), a dignidade da pessoa humana é princípio que unifica e centraliza todo o sistema normativo, assumindo especial prioridade. A dignidade humana simboliza, desse modo, verdadeiro superprincípio constitucional, a norma maior a orientar o constitucionalismo contemporâneo, nas esferas local e global, dotando-lhe de especial racionalidade, unidade e sentido". (PIOVESAN, 2013, p. 89).
} 
irrenunciável e inalienável, na medida em que constitui elemento que qualifica o ser humano como tal e dele não pode ser destacado [...]”.

Na esteira dessa qualificação, notadamente de matriz kantiana, tem-se como plausível a concepção de que a dignidade da pessoa humana é inviolável, como um conceito absoluto, que preponderaria quando em conflito com outros princípios ou até com os próprios direitos fundamentais. Em destacada lição, Alexy $(2015,2016)$ dissolve a controvérsia, a partir de sua teoria dos princípios ${ }^{21}$.

No que concerne à dignidade humana, o jusfilósofo leciona que há duas normas dispondo sobre dignidade humana: a regra da dignidade humana e o princípio da dignidade humana, inexistindo, portanto, um princípio absoluto e inviolável da dignidade ${ }^{22}$. Na lição de Alexy (2015, p. 97), a teoria dos direitos fundamentais e a lei de colisão preconizam a inexistência de direitos absolutos e de relação incondicionada de precedência. Assim, até mesmo o princípio da dignidade da pessoa humana pode sofrer sopesamento quando em conflito.

\section{A DIMENSÃO INTERSUBJETIVA DA DIGNIDADE DA PESSOA HUMANA COMO RESPOSTA PARA A TUTELA DOS DIREITOS FUNDAMENTAIS DO IMIGRANTE}

Problemáticas de significativa expressividade nas dinâmicas contemporâneas dizem respeito aos movimentos migratórios e à crise humanitária. Pessoas fugidas da Síria e de países do Norte da África, notadamente, aventuram-se diariamente na arriscada tentativa de obter para si e seus familiares uma vida digna e justiça social em países ocidentais. Dados da ONU (2016)

\footnotetext{
21 “[...] princípios são normas que ordenam que algo seja realizado na maior medida possível dentro das possibilidades jurídicas e fáticas existentes. Princípios são, por conseguinte, mandamentos de otimização, que são caracterizados por poderem ser satisfeitos em graus variados e pelo fato de que a medida devida de sua satisfação não depende somente das possibilidades fáticas, mas também das possibilidades jurídicas. O âmbito das possibilidades jurídicas é determinado pelos princípios e regras colidentes". (ALEXY, 2015, p. 90, grifo do autor) "Já as regras são normas que são sempre ou satisfeitas ou não satisfeitas. Se uma regra vale, então, deve se fazer exatamente aquilo que ela exige; nem mais, nem menos. Regras contêm, portanto, determinações no âmbito daquilo que é fática e juridicamente possível. Isso significa que a distinção entre regras e princípios é uma distinção qualitativa, e não uma distinção de grau. Toda norma é ou uma regra ou um princípio". (ALEXY, 2015, p. 90, grifo do autor).

22 “[...] é possível dizer que a norma da dignidade humana não é um princípio absoluto. A impressão de um caráter absoluto advém, em primeiro lugar, da existência de duas normas da dignidade humana: uma regra e um princípio; além disso, essa impressão é reforçada pelo fato de que há uma série de condições sob as quais o princípio da dignidade humana prevalecerá - com grande grau de certeza - em face de todos os outros princípios". (ALEXY, 2016, p. 114).
} 
revelam que somente no ano de 2015 aproximadamente um milhão de pessoas atravessou o mar mediterrâneo em busca de abrigo na Europa.

A saída do Estado de origem em direção ao Estado receptor, inclusive no próprio deslocamento, pode representar sérias violações em tema de dignidade da pessoa humana e direitos fundamentais, a partir da vulnerabilidade cultural, econômica e social do imigrante. Seja em âmbito de moradia, saúde e trabalho, seja quanto ao próprio respeito à pessoa em suas liberdades, o âmbito de proteção e a tutela dos direitos fundamentais do imigrante no sistema jurídico do Estado receptor deve ser objeto de análise.

Nesse sentido, faz-se necessário compreender de forma mais abrangente o conteúdo da dignidade da pessoa humana. É possível identificar em Sarlet (2009) que a compreensão real da dignidade requer o seu fracionamento a partir de dimensões. Partes necessárias não para reduzir sua abrangência; pelo contrário, fundamentais para afastar a sua consabida vagueza e generalidade e para alcançar seu verdadeiro significado para a ordem jurídica ${ }^{23}$.

Portanto, o conteúdo da dignidade como algo inerente ao ser humano compreende apenas uma das dimensões. Para o autor, a leitura da dignidade da pessoa humana deve compreender as dimensões ontológica, intersubjetiva, histórico-cultural, negativa e prestacional, a fim de alcançar a maior abrangência do seu conceito e afastá-la das concepções reducionistas e fundamentalistas ${ }^{24}$ :

Abordando de forma breve as três dimensões externas ao tema deste trabalho, o que se mostra suficiente para os objetivos pretendidos, parte-se da perspectiva ontológica da dignidade, enquanto conteúdo mais conhecido, alicerçado na matriz kantiana, que corresponde

\footnotetext{
23 “'[...] necessidade de uma compreensão não reducionista desta dignidade, reforçando a tese subjacente ao próprio título desta coletânea, no sentido de que a dignidade da pessoa humana, seja para a filosofia, seja para o Direito, abrange várias dimensões, que além de não serem incompatíveis entre si (o que nunca impediu, nem nunca impedirá opiniões divergentes) acabam por reforçar a própria proteção da dignidade e até mesmo - por que não dizê-lo - humanizar este conceito que nem sempre serviu de motivação para causas de inequívoca nobreza." (SARLET, 2009, p. 10).

24 “Assim sendo, tem-se por dignidade da pessoa humana a qualidade intrínseca e distintiva reconhecida em cada ser humano que o faz merecedor do mesmo respeito e consideração por parte do Estado e da comunidade, implicando, neste sentido, um complexo de direitos e deveres fundamentais que assegurem a pessoa tanto contra todo e qualquer ato de cunho degradante e desumano, como venham a lhe garantir as condições existenciais mínimas para uma vida saudável, além de propiciar e promover sua participação ativa e co-responsável nos destinos da própria existência e da vida em comunhão com os demais seres humanos". (SARLET, 2009, p. 37 , grifo do autor).
} 
à dignidade como qualidade intrínseca, irrenunciável e própria do ser humano, não necessariamente biológica ${ }^{25}$.

A dimensão histórica e cultural, por sua vez, pretende demonstrar que a noção de dignidade está em constante construção, assim como o conteúdo dos direitos, e, por conseguinte, que não se trata de um conceito fixo e determinado. Depreende-se dessa dimensão que o conteúdo da dignidade da pessoa humana requer atenção à pluralidade das sociedades contemporâneas ${ }^{26}$.

A terceira e última dimensão diz respeito à dúplice tarefa da dignidade, como limite e tarefa do Estado. Dessa classificação, tem-se o limite como capacidade potencial de autodeterminação da pessoa, na impossibilidade de sua coisificação e no direito fundamental de preservar-se da violação da dignidade, ao passo que a tarefa é concepção atribuída ao Estado e à comunidade, como a necessidade de ser protegida, assegurada e promovida ${ }^{27}$.

Ainda sobre a dimensão intersubjetiva, também denominada "dimensão comunicativa e relacional da dignidade da pessoa humana como o reconhecimento pelo(s) outro(s)" 28 , verifica-se um conteúdo que se firma na igualdade em dignidade e no pluralismo e diversidade para justificar a necessária realização da dignidade para todos os seres humanos no espaço coletivo.

Da análise de conteúdo, tem-se que a dimensão intersubjetiva é consectária da dimensão ontológica da dignidade. Isso porque requer um reconhecimento preliminar na esfera

\footnotetext{
25 “[...] verifica-se que o elemento nuclear da noção de dignidade da pessoa humana parece continuar sendo reconduzido - e a doutrina majoritária conforta esta conclusão - primordialmente à matriz kantiana, centrando-se, portanto, na autonomia e no direito de autodeterminação da pessoa (de cada pessoa). Importa, contudo, ter presente a circunstância de que esta liberdade (autonomia) é considerada em abstrato, como sendo a capacidade potencial que cada ser humano tem de autodeterminar sua conduta [...]". (SARLET, 2009, p. 22).

26 “[...] percebe-se (ao menos assim se espera) que com o reconhecimento de uma dimensão cultural e, em certo sentido, também prestacional da dignidade não se está a aderir à concepção da dignidade como prestação, ao menos não naquilo em que se nega ser a dignididade (também) o valor intrínseco reconhecido ao ser humano, mas sim, eminentemente uma condição conquistada pela ação concreta de cada indivíduo, não sendo tarefa dos direitos fundamentais assegurar a dignidade, mas sim, as condições para a realização da prestação" (sic) (SARLET, 2009, p. 29).

27 “[...] sustenta-se que a dignidade possui uma dimensão dúplice, que se manifesta enquanto simultaneamente expressão da autonomia da pessoa humana (vinculada à ideia de autodeterminação no que diz com as decisões essenciais a respeito da própria existência), bem como da necessidade de sua proteção (assistência) por parte da comunidade e do Estado, especialmente quando fragilizada ou até mesmo - e principalmente - quando ausente a capacidade de autodeterminação" (SARLET, 2009, p. 30).

${ }^{28}$ Conforme Sarlet (2009, p. 23).
} 
subjetiva, ou seja, da dignidade intrínseca, própria de cada pessoa, para existir no meio intersubjetivo, sem a qual não encontraria razão de ser e para a qual se mostra necessária, a fim de garantir a dignidade de cada um e da comunidade como um todo ${ }^{29}$.

$\mathrm{Na}$ dicotomia entre universalismo e relativismo, bastante presente no discurso dos direitos humanos e fundamentais, e à luz do multiculturalismo, Fachin (2009) destaca o princípio da tolerância, como mecanismo para possibilitar o diálogo no cenário global marcado pela polarização dos debates e sustenta que a diversidade cultural, em lugar de enfraquecer os direitos, deve ser considerada crucial para o início do diálogo sobre o tema.

A partir do multiculturalismo e da tolerância, torna-se claro que as necessidades dos imigrantes não podem ser simplesmente desconsideradas no sistema jurídico do Estado receptor. A questão da identidade vem se mostrando um vetor na dissociabilidade entre o titular e o não titular de um direito. Ao estrangeiro, na qualidade de imigrante ou refugiado, estaria negada, em tese, a possibilidade de se tornar titular de direitos em igualdade de condições com os cidadãos, pela ausência do pertencimento ao Estado.

Também para Cole (2006, p. 653) a dimensão intersubjetiva da dignidade da pessoa humana é central à titularidade de direitos fundamentais; sustenta o autor que deve ser obstada a distinção entre "cidadãos" e "não cidadãos", no sistema jurídico norte-americano, quanto aos direitos humanos, mencionando: "human rights law, predicated on human dignity, does not distinguish between citizens and notcitizens".

Carens (2008) prega que enquanto todo o cidadão deve gozar de maneira equitativa dos direitos estabelecidos pela ordem jurídica, para os não cidadãos, no que se inclui os migrantes e os turistas, deve ser assegurado um rol de direitos humanos universais, que independem da cidadania e da soberania estatal. Defende, portanto, a existência de direitos humanos universais, usufruíveis de forma idêntica por cada ser humano, a despeito de seu status perante o Estado.

Por outro lado, no tratamento jurídico alçado aos cidadãos e aos estrangeiros residentes, concebe a necessidade de estabelecer diferenças. Assim, o autor particulariza a titularidade dos

29 “[...] noção da dignidade como produto do reconhecimento da essencial unicidade de cada pessoa humana e do fato de esta ser credora de um dever de igual respeito e proteção no âmbito da comunidade humana". (SARLET, 2009, p. 27). 
direitos políticos e resguarda aos cidadãos uma tutela maior no que concerne a empregos públicos, moradia e programas sociais em comparação aos estrangeiros residentes ${ }^{30}$. Porém, mostra-se oposto à ideia de negar aos imigrantes a totalidade de direitos sociais disponíveis ${ }^{31}$.

O pluralismo integra o discurso de Arendt (2016) em sua análise da condição humana. Afirma que o trabalho, a obra e a ação consubstanciam três condições fundamentais básicas para a vida do homem no planeta, sendo que a ação é a atividade que se desenvolve no plano da intersubjetividade ${ }^{32}$. Essa pluralidade repercute sobre a identidade do ser, pois ao tempo em que preconiza a igualdade, traduz a diversidade e a identidade da pessoa ${ }^{33}$.

Quanto à discussão pelo reconhecimento, Honneth (2003) relaciona as esferas do amor, do direito e da solidariedade, como formas de reconhecimento nos conflitos sociais. O direito se revela pelo respeito próprio, na relação com "o outro". Tem-se, portanto, que o entendimento do real alcance da dimensão intersubjetiva da dignidade da pessoa humana requer a compreensão das dinâmicas de reconhecimento.

Sarlet $(2015$, p. 215,217$)$ distingue titulares de destinatários, em termos de direitos fundamentais - tão comumente confundidos. Afirma que o termo "titular" concerne ao sujeito ativo da relação, a quem pertence o direito, ao passo que o termo "destinatário" é a quem ou ao que se opõe o comando, o preceito que afirma esse direito, como sujeito passivo da relação jurídico-objetiva, a quem se impõe o dever jurídico de respeitar, proteger ou promover esse direito. Adita que o princípio da universalidade alberga o direito de todas as pessoas de figurarem como titulares de direitos e deveres fundamentais, sem representar, necessariamente, que a todos estão garantidos todos os direitos fundamentais. Nesse sentido, traz o caso

\footnotetext{
30 “Apart from voting and holding public office (both of which I think can properly be reserved for citizens, given easy naturalisation), there are two main areas where citizens enjoy more rights than residents, public employment and security of residence, and a third, access to social programs, where some people think the differentiation should be much sharper" (CARENS, 2008, p. 11).

31 "There has been a move lately (as in the US 1996 legislation) to restrict the access of recent immigrants to various forms of social assistance. I think this is unwelcoming and unwise, but I would not say that it is unjust so long as it applies only to recent arrivals. As I argued above, claims to membership grow over time. That means that they are weaker at first, so it is not unjust to restrict access to redistributive social programs to those with claims to full membership. But long-term residents fit in this category on my account. They are entitled to be treated as full members. So, proposals to ban immigrants forever from social assistance programs would clearly be unjust". (CARENS, 2008, p. 11-12).

32 "A pluralidade é a condição da ação humana porque somos todos iguais, isto é, humanos, de um modo tal qual que ninguém jamais é igual a qualquer outro que viveu, vive ou viverá". (ARENDT, 2016, p. 10).

${ }^{33}$ Conforme Arendt (2016, p. 217-224).
} 
constitucional pátrio, que distinguiu os brasileiros dos estrangeiros e os estrangeiros residentes dos não residentes.

O autor assevera que, muito embora não se trate de um direito expresso no texto constitucional, não há como afastar algum direito fundamental aos estrangeiros não residentes. Com arrimo nos princípios da dignidade da pessoa humana e da universalidade, defende que determinados direitos são extensíveis, ao menos os direitos que tenham fundamento na dignidade da pessoa humana (SARLET, 2015, p. 220).

Resta sedimentada a concepção de que os estrangeiros, sejam eles imigrantes ou refugiados, devem estar protegidos, ao menos em nível mínimo, no sistema jurídico do Estado receptor. Numa perspectiva multicultural alicerçada na igualdade em dignidade, na ética da tolerância e no reconhecimento do outro no espaço coletivo, o estrangeiro não deve ser esquecido e suas necessidades, ponderadas.

Sob esse prisma, emerge a dignidade da pessoa humana, como resposta e instrumento a justificar a titularidade de direitos fundamentais do outro. A dimensão intersubjetiva da dignidade apregoa o universalismo no escopo do tratamento digno, a partir do qual todos são iguais em dignidade, tratando dessa igualdade e do reconhecimento da pessoa no espaço coletivo. Portanto, não é razoável rejeitar a tutela dos direitos fundamentais ao imigrante, isso em atenção ao pertencimento do homem à coletividade e ao dever recíproco de garantia da dignidade da pessoa humana.

\section{CONCLUSÃO}

O presente trabalho traz como primeiros resultados de pesquisa recém iniciada, construída para investigar a possibilidade de o estrangeiro se tornar titular de direitos fundamentais, tendo por base a concepção dogmática da dimensão intersubjetiva da dignidade da pessoa humana. As graves violações aos direitos humanos cometidos em detrimento de imigrantes e refugiados nos últimos anos consubstanciaram-se em fortes razões para investigar de que maneira a dignidade da pessoa humana e seu escopo de proteção interferem na tutela dos direitos fundamentais desses sujeitos. 
Observou-se que a dignidade da pessoa humana detém relevância na instrumentalização e possibilitação dos direitos humanos e fundamentais, integrando grande parte dos documentos internacionais que regem a temática dos direitos. Em linhas gerais, é reconhecida como qualidade intrínseca e inerente do ser humano, constituindo-se em um verdadeiro valor fundamental na dogmática constitucional interna e internacional.

Conquanto ainda detenha um conceito vago e impreciso, a dignidade da pessoa humana não pode estar limitada ao conceito comum, reducionista; melhor, incumbe à doutrina e filosofia jurídicas estudar a dignidade a partir de suas múltiplas dimensões, com arrimo na concepção multifacetada do ser humano e nas dinâmicas da coletividade. Nesse sentido, emerge a dimensão intersubjetiva, segundo a qual há um dever recíproco de respeitar e proteger a dignidade do outro no espaço coletivo.

Em tema de movimentos migratórios e crise humanitária, o imigrante vivencia certa vulnerabilidade e fica sujeito à redução ou eliminação de determinados direitos e do tratamento digno que lhe é devido. A depender do Estado receptor e seu sistema jurídico, o imigrante pode até vir a perder sua identidade enquanto pessoa e, portanto, não existir no mundo jurídico, enquanto sujeito de direitos, conjuntura dissonante do apregoado pela dimensão intersubjetiva apresentada neste trabalho.

À guisa de conclusão, verificou-se plausível a hipótese centrada na tutela dos direitos fundamentais do imigrante a partir da dignidade da pessoa humana e de sua dimensão intersubjetiva. Isso porque essa dimensão preconiza uma igualdade em dignidade para todos os seres humanos, dogmática que se faz necessária para a proteção e segurança do espaço coletivo multicultural. A delimitação da gama de liberdades e de prestações jurídicas que são devidas aos imigrantes deve ser objeto, contudo, do aprofundamento desta pesquisa.

O mundo hoje testemunha diversos fluxos migratórios que bem materializam o estado de intensa instabilidade das relações humanas e políticas, em busca de estabilização em ambiente de paz para o desenvolvimento da vida em sociedade. Só isso já justifica a importância de estudar o tema, entretanto, a fim de enfatizar o argumento, convém rememorar que, não apenas as guerras mundiais maltrataram pessoas de outras nacionalidades, também o Brasil, em contexto de tempo de paz, protagonizou omissão estatal sob a forma de exploração desumana 
de imigrantes advindos da I Guerra para substituir mão de obra camponesa; assim como em outra leva, de fugitivos e retirados dos horrores da II Guerra; e, assustadoramente, nos dias de hoje, ainda tolera a exploração de estrangeiros, oriundos da Bolívia, Paraguai e países orientais - "neo-escravizados”, vivendo, não em distantes latifúndios, mas em cubículos produtivos, em pleno centro de São Paulo. Isso precisa ter um fim.

\section{REFERÊNCIAS}

ALEMANHA. Tribunal Constitucional Federal. Introdução. In: SCHWABE, Jürgen. Cinquenta anos de jurisprudência do Tribunal Constitucional Federal Alemão. Tradução de Leonardo Martins et al. Montevidéu: Fundação Konrad Adenauer, 2005.

ALEXY, Robert. Teoria dos Direitos Fundamentais. 2. ed. 4. tiragem. Tradução de Virgílio Afonso da Silva da 5. ed. alemã. São Paulo: Malheiros, 2015a.

. A dignidade humana e a análise da proporcionalidade. Tradução de Rogério Luiz Nery da Silva. In: ALEXY, R.; BAEZ, N. L. X. e SILVA, R. L. N. da (Org.). Dignidade Humana, Direitos Sociais e Não-positivismo Inclusivo. Florianópolis: Qualis, 2015b. p. 1338 .

ARENDT, Hannah. A condição humana. Tradução Roberto Raposo. Revisão técnica e apresentação Adriano Correia. 12 ed. rev. Rio de Janeiro: Forense Universitária, 2016.

BAEZ, Narciso Leandro Xavier; MOZETIC, Vinicius Almada. A morfologia das teorias universalistas dos direitos humanos fundamentais. In: ALEXY, R.; BAEZ, N. L. X.;

SANDKÜHLER, H. J. Níveis de efetivação dos direitos fundamentais civis e sociais: um diálogo Brasil e Alemanha. Joaçaba: Editora Unoesc, 2013, p. 17-66.

BARCELLOS, Ana Paula de. A eficácia jurídica dos princípios constitucionais: o princípio da dignidade da pessoa humana. $3^{\text {a }}$ ed. revista e atualizada. Rio de Janeiro: Renovar, 2011.

BOBBIO, Norberto. A era dos direitos. Tradução de Carlos Nelson Coutinho. Apresentação de Celso Lafer. Nova edição. Rio de Janeiro: Elsevier, 2004.

BRASIL. Lei $n^{\circ}$ 6.815, de 19 de agosto de 1980. Define a situação jurídica do estrangeiro no Brasil, cria o Conselho Nacional de Imigração. Disponível em http://www.planalto.gov.br. Acesso em $1^{\circ}$ ago. 2016. 1988.

Constituição da República Federativa do Brasil. Brasília, DF: Senado Federal,

Lei $n^{\circ} 9.474$, de 22 de julho de 1997. Define mecanismos para a implementação do Estatuto dos Refugiados de 1951 e determina outras providências. Disponível em http://www.planalto.gov.br. Acesso em $1^{\circ}$ ago. 2016. 
Ministério da Justiça. Comitê Nacional para os Refugiados. Sistema de Refúgio Brasileiro - Desafios e Perspectivas. [2016]. Disponível em http://www.acnur.org/portugues/recursos/estatisticas/dados-sobre-refugio-no-brasil/. Acesso em: 04 set. 2016.

CARENS, Joseph H. Immigration, Democracy, and Citizenship. [2008]. Disponível em: http://isites.harvard.edu/fs/docs/icb.topic162929.files/E_European_enlargement/Carens.pdf. Acesso em 04 set. 2016.

CARTA AFRICANA DOS DIREITOS HUMANOS E DOS POVOS [1981]. Disponível em http://www.direitoshumanos.usp.br. Acesso em 02 ago. 2016.

COLE, David. The idea of humanity: human rights and immigrants'rights. In: Columbia Human Rights Law Review, Estados Unidos da América, v. 37, n. 3, p 627-658, 2006.

COMPARATO, Fábio Konder. A afirmação histórica dos direitos humanos. 3 ed. rev. e ampl. São Paulo: Saraiva, 2003.

DECLARAÇÃO ISLÂMICA UNIVERSAL DOS DIREITOS HUMANOS [1981]. Disponível em http://www.direitoshumanos.usp.br. Acesso em 02 ago. 2016.

FACHIN, Melina Girardi. Fundamentos dos direitos humanos: teoria e práxis na cultura da tolerância. Rio de Janeiro: Renovar, 2009.

HONNETH, Axel. Luta por reconhecimento: a gramática moral dos conflitos sociais. Tradução de Luiz Repa. Apresentação de Marcos Nobre. São Paulo: Ed. 34, 2003.

ONU. Declaração Universal dos Direitos Humanos. [1948]. Disponível em http://www.onu-brasil.org.br. Acesso em 15 jul. 2016.

Global Trends: Forced Displacement in 2015 [2016]. Disponível em: http://www.acnur.org. Acesso em $1^{\circ}$ out. 2016.

PIOVESAN, Flávia. Direitos Humanos e o Direito Constitucional Internacional. 14. ed., rev. e atual. São Paulo: Saraiva, 2013.

SANDKÜHLER, Hans Jörg. A dignidade humana como fundamento dos direitos humanos. O exemplo da Constituição da República Federal da Alemanha. In: ALEXY, R.; BAEZ, N. L. X.; SANDKÜHLER, H. J. Níveis de efetivação dos direitos fundamentais civis e sociais: um diálogo Brasil e Alemanha. Joaçaba: Editora Unoesc, 2013, p. 99-138.

SARLET, Ingo Wolfgang. As dimensões da dignidade da pessoa humana: construindo uma compreensão jurídico-constitucional necessária e possível. In. SARLET, Ingo Wolfgang (Org.). Dimensões da Dignidade: ensaios de filosofia do direito e direito constitucional. 2. ed. rev. e ampl. Porto Alegre: Livraria do Advogado Editora, 2009, p 15-44. 
A eficácia dos direitos fundamentais: uma teoria geral dos direitos

fundamentais na perspectiva constitucional. 12. ed. rev. atual e ampl. Porto Alegre:

Livraria do Advogado Ed., 2015.

SCHWARZ, Rodrigo García. Los derechos sociales como derechos humanos fundamentales: Su imprescindibilidad y sus garantías. México, Editora Miguel Ángel Porrúa, 2011.

TORRES, Ricardo Lobo. O mínimo existencial, os direitos sociais e os desafios de natureza orçamentária. In: SARLET, Ingo Wolfgang; TIMM, Luciano Benetti (Org.).

Direitos Fundamentais: orçamento e "reserva do possível". 2. ed. rev. e ampl. 2 tiragem. Porto Alegre: Livraria do Advogado Editora, 2013. 